Jordi Mancebo Massimo Antonelli

\title{
Editors' comments on a new trial of activated \\ protein C for persistent septic shock
}

Received: 18 September 2008

Accepted: 18 September 2008

Published online: 7 October 2008

(C) Springer-Verlag 2008

This editorial refers to the article available at: doi:10.1007/s00134-008-1266-6.

\section{J. Mancebo (四)}

Servei de Medicina Intensiva, Hospital de Sant Pau, Av. S.A.M. Claret 167, 08025 Barcelona, Spain

e-mail:jmancebo@santpau.cat

\section{Antonelli}

Department of Intensive Care and Anesthesiology,

Policlinico Universitario A. Gemelli,

Università Cattolica del Sacro Cuore,

Largo A. Gemelli, 8, 00168 Rome, Italy

e-mail: m.antonelli@rm.unicatt.it

This month's issue of the Journal contains a somewhat unusual article and two accompanying editorials [1-3]. The authors of the article are members of the steering committee of an ongoing Eli-Lilly trial on activated protein $\mathrm{C}$ for persistent septic shock. They describe a number of steps that have been adopted in order to ensure transparency in disclosing financial conflicts, facilitate comprehension and interpretation of results, minimize possible risks, and maximize eventual benefits for patients. This approach constitutes a new model of academia-industry collaboration.

The importance of the initiative is that the study will or will not confirm the results obtained in a pivotal trial [4] that has evoked bitter controversy over recent years. Such debate is founded on issues of inconsistency in results, possible risks of treatment, and lack of reproducibility of data [5-12]. Furthermore, Eli-Lilly was criticized for conducting what has been viewed as a carefully targeted advertising campaign $[13,14]$.

One may reasonably argue that by publishing this article, we in some way promote this new Eli-Lillysponsored trial. One may also point out that this could be a subtle way to help recruit subjects into the trial. And it may also appear that Intensive Care Medicine, the official journal of the European Society of Intensive Care Medicine, hereby endorses this trial.

However, this is not the case. The Journal decided to publish the article and the two editorials for a number of reasons. First of all, the authors clearly state their financial conflicts with the sponsor and outline their relationship with Eli-Lilly in full. Second, our aim is to provide the public and also physicians enrolling subjects into this trial with further scientific background on activated protein $\mathrm{C}$. Third, we wish to emphasize that publication of this article and the investigation protocol (as an electronic supplementary material file) in no way implies an imprimatur by Intensive Care Medicine. Fourth, although there is still far to go before we reach an ideal scenario of industry-researcher collaboration, we welcome this unprecedented step forward. And lastly, we believe this trial is fundamental in order to comply with one of the major requirements of medical science: reproducibility.

The novelty here is the full disclosure of the process by which this study was designed, and a description of how it will be conducted, analyzed and reported. We thank the authors, the reviewers and the editorialists for their fair and honest commitment to maintaining the integrity of the editorial process. We hope all this will facilitate rigorous interpretation of the data and will contribute to the dissemination of scientific information that can help clinicians, our readers, to serve better their patients. 


\section{References}

1. Finfer S, Ranieri V, Thompson B, Barie P, Dhainaut J, Douglas I, Gardlund B, Marshall J, Rhodes A (2008) Design, conduct, analysis and reporting of a multi-national placebocontrolled trial of activated protein $\mathrm{C}$ for persistent septic shock. Intensive Care Med. doi:10.1007/s00134-008-1266-6

2. Sweeney DA, Danner RL, Eichacker PQ, Natanson C (2008) Once is not enough: clinical trials in sepsis. Intensive Care Med 34. doi: 10.1007/s00134-008-1274-6

3. Takala J, Suter PM (2008) Science, medicine and industry: are we getting out of the black hole in sepsis research. Intensive Care Med 34. doi: 10.1007/s00134-008-1302-6

4. Bernard GR, Vincent J-L, Laterre P-F, LaRosa SP, Dhainaut J-F, Lopez-Rodriguez A, Steingrub JS, Garber GE, Helterbrand JD, Ely EW, Fisher CJ (2001) Efficacy and safety of recombinant human activated protein $\mathrm{C}$ for severe sepsis. N Engl J Med 344:699-709
5. Wenzel RP (2002) Treating sepsis. N Engl J Med 347:966-967

6. Warren HS, Suffredini AF, Eichacker PQ, Munford RS (2002) Risks and benefits of activated protein $C$ treatment for severe sepsis. N Engl J Med 347:1027-1030

7. Siegel JP (2002) Assessing the use of activated protein $\mathrm{C}$ in the treatment of severe sepsis. N Engl J Med 347:1030-1034

8. Ely EW, Bernard GR, Vincent J-L (2002) Activated protein $\mathrm{C}$ for severe sepsis. N Engl J Med 347:1035-1036

9. Eichacker PQ, Danner RL, Suffredini AF, Cui X, Natanson C (2005) Reassessing recombinant human activated protein $\mathrm{C}$ for sepsis: time for a new randomized controlled trial. Crit Care Med 33:2426-2428

10. Bertolini G, Rossi C, Anghileri A, Livigni S, Addis A, Poole D (2007) Use of Drotrecogin alfa (activated) in Italian intensive care units: the results of a nationwide survey. Intensive Care Med 33:426-434
11. Kanji S, Perreault MM, Chant C, Williamson D, Burry L (2007) Evaluating the use of Drotrecogin alfa (activated) in adult severe sepsis: a Canadian multicenter observational study. Intensive Care Med 33:517-523

12. Eichacker PQ, Natanson C (2007) Increasing evidence that the risks of rhAPC may outweigh its benefits. Intensive Care Med 33:396-399

13. Eichacker PQ, Natanson C, Danner RL (2006) Surviving sepsis-practice guidelines, marketing campaigns, and Eli Lilly. N Engl J Med 355:1640-1642

14. Ranieri VM, Moreno RP, Rhodes A (2007) The European Society of Intensive Care Medicine (ESICM) and the Surviving Sepsis Campaign (SSC). Intensive Care Med 33:423-425 